Bakhov Ivan.

Doctor of Pedagogical Sciences, Associate Professor, head of the department of foreign philology and translation of the Interregional Academy of Personnel Management

ORCID 0000-0002-8379-199X bakhov@ukr.net

\title{
MAIN AREAS OF THE IMPLEMENTATION OF MULTICULTURALISM IN PROFESSIONAL EDUCATOR TRAINING IN THE USA
}

The purpose of the research. The article raises the problem of professional preparation of future educators in the United States and Canada for work in a multicultural educational environment. Research methodology is based on the use of comparative and analytical methods while studying the works of American and Canadian scholars dealing with issues of ethnocultural diversity of the educational environment of modern educational institutions and attempts to resolve them from the standpoint of a tolerant attitude in working with multiethnic and multicultural students. Scientific novelty lies in the analysis of conceptual and empirical studies of American and Canadian authors, which until now have not been highlighted in the Ukrainian press. Conclusions. The research shows that teacher training programs at US colleges and universities, the curriculums and the policies of educational institutions have been revised to focus on the diversity of the ethnic composition of students and teachers, and that they reflect the main requirements to the goals and objectives of multicultural education.

Keywords: culture; multicultural; multiethnic; environment; the USA; Canada; curriculum; education.

Бахов Іван Степанович, доктор педагогічних наук, дочент, завідувач кафредри іноземної фрілології та перекладу Міжрегіональної Академії управління персоналом

Основні напрями реалізації мультикультуралізму у професійній підготовці викладачів у США

Мета роботи - дослідити професійну підготовку майбутніх вчителів у США та Канаді для роботи в багатокультурному освітньому середовищі. Методологія дослідження ґрунтується на застосуванні компаративного та аналітичного методів у дослідженні праць американських та канадських вчених, присвячених питанням етнокультурного розмаїття навчального середовища сучасних навчальних закладів та спроб їх вирішення 3 точки зору толерантного ставлення до роботи з багатонаціональними та мультикультурними студентами. Наукова новизна полягає в аналізі концептуальних та емпіричних досліджень американських та канадських авторів, які досі не були висвітлені в українській пресі. Висновки. В результаті дослідження показано, що програми підвищення кваліфрікації вчителів американських коледжів та університетів, навчальні плани та політика навчальних закладів зазнають змін з метою зосередження уваги на різноманітті етнічного складу студентів та вчителів, а також відображають основні вимоги до цілей та завдань багатокультурної освіти.

Ключові слова: культура; мультикультурний; багатоетнічний; навколишнє середовище; навчальний план; освіта.

Бахов Иван Степанович, доктор педагогических наук, доцент, заведующий кафедрой иностранной филологии и перевода Межрегиональной Академии управления персоналом подавателей в США

Основные направления реализации мультикультурализма в профессиональной подготовке пре-

Цель работы - исследовать профессиональную подготовку будущих учителей в США и Канаде для работы в поликультурном образовательном среде. Методология исследования основана на применении сравнительного и аналитического методов в изучении работ американских и канадских ученых, посвященных вопросам этнокультурного разнообразия образовательной среды современных учебных заведений и попыток их решения с точки зрения толерантного отношения к работе с многонациональными и мультикультурными студентами. Научная новизна заключается в анализе концептуальных и эмпирических исследований американских и канадских авторов, до сих пор не были освещены в украинской прессе. Выводы. В результате исследования показано, что программы повышения квалификации учителей американских колледжей и университетов, учебные планы и политика учебных заведений изменяются с целью сосредоточения внимания на многообразии этнического состава студентов и учителей, а также отражают основные требования к целям и задачам многокультурной образования.

Ключевые слова: культура; многокультурный; многонациональный; образовательная среда; США; Канада; учебная программа; образование.

Problem statement. The state of culture and society is determined by the structural and content features of the education system. In other words, every nation has the educational system that corresponds to the state of its culture and society, to the needs of its self-preservation and development. Therefore, it is important to address the social and political conditions that influenced the formation and development of multicultural education in the United States.

The objective of the article is to analyze the scientific works of American and Canadian scientists published in the 1990s and 2000s, which contain the results of conceptual and empirical studies that have not been disclosed to the present day in the Ukrainian press.

(C) Bakhov I., 2018 
Analysis of papers with theoretical frameworks. Analysis of literature on multicultural education allows to single out a significant number of studies devoted to teacher training. Efforts aimed at making teacher education multicultural, and, consequently, responsive to requirements of the multicultural environment of an educational institution and society as a whole, through government policy, reforming educational programs, selecting students and teachers, various organizational changes in the work of higher education establishments, are reflected in works of a number of American and Canadian scholars [1; 5]. As analysis of literature showed, the beginning of the XXI century can be considered the most successful and, at the same time, the most difficult period for the multicultural teacher training $[7 ; 14 ; 15]$.

On the one hand, it was time of hope, a period of increased attention to issues of ethnocultural diversity of the learning environment [2]. For example, during his election campaign, George Bush said that "no student should be left unattended," emphasizing the responsibility of the American education system for increasing the achievement of each student [7].

Let us note another positive moment: despite the fact that North American national professional organizations did not address problems of multicultural education until the 1970s, all major national organizations involved in the accreditation of teacher training programs, licensing and issuance of professional advancement certificates, had at the time clear requirements for the competence of a teacher to work with multiethnic and multicultural students [19].

According to a study by D. Gollnick, published in 1995 with the title "National and State Initiatives for Multicultural Education", by 1993, 16 out of the 17 national curriculum standards in the USA approved by the National Council for the Accreditation of Teacher Education (NCATE) contained multicultural principles, and in 40 states, bilingual education and compulsory study of the culture of ethnic groups were introduced into middle school curriculums and teacher training programs [11].

Research by G. Ladson-Billings and K. Zeichner [17] also confirms that almost throughout the country, teacher training programs at colleges and universities, curriculums and policies of educational institutions by the early 1990s were reviewed for attention to the diversity of the ethnic composition of students and teachers and reflected the main requirements of the goals and objectives of multicultural education.

Positive moments of this period without doubt include the rich theoretical knowledge of the key issues of multicultural education, including teacher training, accumulated by American and Canadian scholars, compared with the 1970s-1980s, when theorists noted significant lack of works on these issues [3; 6; 21].The fact that the number of Americans of color among schoolteachers, students, and college teachers increased is also indicative of progress during this period in the field of multicultural education.

The beginning of the XXI century can also be called the most difficult period for multicultural education, as, along with active transformations in its favor, there were no less active obstacles characterized by many scholars as threatening for policy of multiculturalism. For example, according to B. Gordon, in many states, there was strong resistance to the program of affirmative action in the field of education aimed at introducing bilingual education and eliminating racial discrimination in admitting high school graduates to colleges and universities [12].

According to another researcher, G. Toppo, in a number of states, an "original" way of assessing the quality of work of teachers and of the school as a whole, which included obligatory testing students in all subjects, was proposed. In this case, the test developers did not take into account unequal abilities of students to acquire knowledge. This problem was widely discussed in the media. For example, the Washington Post noted that the "Act on Elementary and Secondary Education", renamed by George Bush in "No Child Left behind Act", should have been called "No Child Left Untested Act" [22].

A number of multicultural scholars observed that only individual attempts were made to introduce the multicultural component into the educational process throughout the country, but fundamental changes in the field of educational policy did not take place [14; 17]. Teachers as a whole, as before, received monocultural education, which brought to the fore universal pedagogical knowledge and excluded from training programs such important questions as racial, class, gender, and cultural characteristics of students and the ability of teachers to correctly rely on these differences in the educational process, considering them as advantages of the learning environment.

Along with the noted difficulties of this period, many critics point out that common steps in the field of reforming pedagogical education (for example, the inclusion of multicultural courses in teacher training programs) were "beautiful, but shallow, thus becoming more rhetorical than real" [23]. Several authors agree that such courses were separate elements added to core curricula rather than an integral part of multicultural curricula (ibid). In other words, the abolition of these courses would not have been reflected in curricula as a whole. The negative aspects of this period also seem to include the fact that the government-funded leading studies did not touch upon issues of preparation of teachers for work in a multicultural classroom, upon specific problems of urban schools that were in urgent need for teaching staff, as statistics confirmed that most teachers left their work because of difficult conditions (low salaries, dangerous, often criminal conditions on the premises of the school, etc.).

Another serious obstacle to the introduction of multicultural programs of teacher training was the false assumption that multiculturalism is primarily a political movement directed against white Americans [8]. It is difficult to grasp the essence of pedagogical research and policy of changes in the field of multicultural 
teacher training without resorting to the broader context of pedagogical education, namely the demographic composition of students and teachers, and to the key issues in reforming pedagogical education.

In the early 1990s, J. Banks introduced the term "demographic imperative" to draw attention to the inequality that was deeply ingrained in the American educational system. According to J. Banks, demographic imperative includes statistical and other information according to three criteria: the diverse composition of students, the homogeneous (in terms of ethnicity) composition of teachers, and the "demographic division" (pronounced discrepancies in educational opportunities, resources, and achievements among students that differ in racial, cultural, and socio-economic characteristics) [3].

As $\mathrm{H}$. Hodkinson points out, according to the data from the 2001-2002 census, the proportion of nonwhite students in the country as a whole was $40 \%$, but this figure ranged from 7 to $68 \%$ depending on the state. In his report, $\mathrm{H}$. Hodkinson emphasizes that the increase of the US population is uneven in terms of ethnicity: in the next 20 years, it is expected that $60 \%$ of the population will be Latin American (40\%) and Asian (20\%); in the state of California, for example, more than half of the inhabitants are of Mexican origin. No other country in the world is marked by such an influx of immigrants as the United States. It is anticipated that by 2035 , the number of students of color in the country will reach $57 \%$ [23].

The ethnic composition of teachers in the United States is just the opposite due to the fact that the number of white teachers in the country is the majority $(86 \%)$ compared to the number of teachers of color (14\%) (National Center for Education Statistics, 2002). These figures, in the opinion of many scholars, are due to the fact that the number of students of color, who attend colleges of pedagogy is lower just as before (the findings are striking because of their discrepancy, since white students constitute from 80 to $93 \%$ ) (American Association of Colleges for Teacher Education, 1999).

Discussion. Demographic data are indicative not only of a numerical discrepancy between the ethnic composition of students and teachers, but also of a noticeable difference in their biographies. In other words, most teachers, as it was mentioned above, are white Anglo-Americans, have a middle-class social status, therefore, since childhood, they grew up under quite favorable conditions that allowed them to obtain a good education in their native language, usually in English.

On the other hand, most students are from low-income, non-white families, for whom English is not their native language, and are familiar with life difficulties from childhood. Many teachers are not familiar with the culture and ethno psychological peculiarities of their students, so any difficulties are considered by the teacher as the student's reluctance or inability to study a particular subject. As G. Gay rightly observes, it is very difficult for teachers and students to find common ground because they come from different worlds with their own laws, environment, values, views on the existing order, therefore it is difficult for a teacher to be an example for students, a person they can trust with their experiences and receive in response some wise advice [10]. Researchers A. Goodwin and A. Villegas \& T. Lucas draw attention to different social and ethnic origin of teachers and students, emphasize that a teacher, who has received monocultural training cannot function as "an agent of culture" helping a student to overcome difficulties of adapting to school because of differences in the requirements of the family education and of the school environment [23].

According to many researchers, the most common mistake of teachers is incorrect perception of ethnic differences of students in the classroom, that is, attitude toward this fact like toward an obstacle to be overcome. The results of observation of the work of teachers in a number of schools have shown that a teacher either ignores an ethnic minority, or tries to assimilate it into the majority, running into additional difficulties, as some students of color resent to their likeness their assimilation into the white majority in the classroom. Moreover, white teachers in advance label students of color as 'unable to study' and have low educational expectations of them [10].

J. Banks believes that the next aspect of "demographic imperative" refers to the inadequacy of educational opportunities, achievements, living conditions, and learning of students differing in racial, cultural, and socioeconomic characteristics. Detailed analysis of these discrepancies and the reasons for their occurrence is presented in the work by A. Villegas \& T. Lucas, who, in their turn, relied widely on data of educational statistics and the results of their own long-term research [23]. They note that, among the developed countries of the world, the highest percentage of children living in poverty is noted in the United States, the number of low-income children of color being much higher than the number of low-income white children (42 and $16 \%$ respectively). The level of educational achievements of students of color in mathematics and reading, according to the National Assessment of Educational Progress (NAEP), is noticeably lower than the level of the respective abilities of their white peers. Scientists conclude that "the incredible gap in the achievement of white students and students of color, as well as a noticeable difference in the numbers of high school graduates (more than half of the students of color do not finish school) are indicative of the inability of the existing educational system to teach children of US citizens of color at schools" [18].

The conditions in which children study are characterized by no less pronounced discrepancies. For example, the provision of schools with the necessary equipment, furniture, educational literature, sports equipment, computers, differs at urban, suburban, and rural schools [9; 17]. In this regard, in the state of California, in 2000, the Union of Civic Initiatives filed a lawsuit on behalf of 18 schools that accused the authorities of lack of proper conditions at schools for work and study. In this suit, it was emphasized that all students regardless of race $(96.4 \%$ of the students of these schools were of color) had the full right to receive from the 
State all the necessary conditions for adequate education - from the premises of a school specially equipped for the safe stay of children in it during the day, equipped with training equipment and materials, to specially trained staff responsible for each child.

J. Banks concluded that "demographic imperative" is, first and foremost, awareness of the fact that overcoming the great gap between the requirements of the learning environment and the life experiences of students from different racial, cultural, and social groups dictates the urgent need for introducing changes in teacher training. Certainly, this will not solve all the problems of the American educational system, but the need for specialists of a new type has reached its limit; today's teachers cannot cope with their main purpose - to give quality education to each child, and so, thereby, the authority of the national school is undermined" [3].

In 1972, the first Commission on Multicultural Education under the American Association of Colleges for Teacher Education (AACTE) was established. It resolved that: 1) cultural diversity is a valuable source; 2) multicultural education preserves and enriches this source, and not only teaches a tolerant attitude; 3) cultural pluralism should be present in all aspects of teacher training programs [4].

The report of the Commission on Multicultural Education began with the main goal and objectives of teacher training: "We are confident that our teachers are able to bring educational equality into schools; to this end, it is necessary to set for teacher training programs a goal - to provide students of pedagogical colleges with the skills necessary to work with multicultural composition of students, so that no child in the classroom is left without the attention of the teacher. This goal sets new tasks, namely, whether teachers of pedagogical colleges are able to work in a new way, whether the former methods of working with students are suited to solve new tasks, whether they need to be modernized taking into account the goals and objectives of multicultural education..." [4].

In 1976, the National Council for the Accreditation of Teacher Education (NCATE) included multicultural education in its standards, stressing that every teacher training educational institution, to receive accreditation, should include multicultural education in all programs until 1981. As analysis of literature showed, since this period, the attention of scientists and critics was directed to the policy of pedagogical education as well as to the state of the theory and practice of teacher training, taking into account the goals and objectives of multicultural education.

We have analyzed leading studies on the gradual introduction of multicultural education into teacher training, which were published in the 1990-2000s in central editions on education, such as Review of Research in Education (RRE), Review of Educational Research (RER), and in the collective monograph "Guide to Research on Pedagogical Education". Summarizing the results of the analysis, we would like to emphasize that the authors repeatedly point out to lack of empirical studies on the problem of teacher training. For example, S. Grant \& W. Secada emphasize that theoretical developments should be "translated into the language of school practice" [13, 405].

G. Ladson-Billings notes increased interest of scientists in issues of multicultural education, but the practical utility of their works, according to the author, leaves much to be desired. The author also concludes that "multicultural teacher training plays the role of mediator between the theory and the practice of multicultural education and, thus, the quality of research on this issue will determine the future fate of multicultural education" [17]. In a 1999 overview, G. Landson-Billings concludes that the problem of cultural diversity never became central to teacher training; just as before, its solution is complementary to existing programs, while fundamental paradigmatic changes are needed. The author proposes the development of new teacher training programs based on the main principles of the critical theory of race [17].

K. Zeichner and K. Hoeft particularly emphasize lack of research on the problem of the interrelation between structural components of programs and the practice of teacher training; between cultural knowledge and the cross-cultural competence of a teacher; between pedagogical experience of a teacher and changes of personal and professional nature.

L. Weiner focuses his review on the problem of preparing a teacher for an urban school, which has a number of specific features, namely "a diverse students' composition, a complex bureaucratic system, constant funding gap, and unitary ideas of intelligence and achievements." The scientist systematized works published in the 1960s-1990s according to the following criteria: skills and relations necessary to work with the category of students who, since childhood, are deprived of favorable conditions for life and study (disadvantaged children); specific changes in teacher training to arm teachers with these skills; the influence of the structure of urban schools on the work of a teacher and the activities of students; emphasis in pedagogical preparation on the features of the environment of an urban school, so that a teacher can give high-quality education to all children and does not want to leave his/her work.

K. Sleeter summarized studies published in the 1970s-1990s on the preparation of a teacher for working with students belonging to social groups that have historically experienced discrimination (children of immigrants, indigenous Americans, and other representatives of the non-white population of the country) [21]. Based on the results of her research, K. Sleeter concludes that most works are scholastic in nature, that is, they are separated from real life and practice. In addition, a serious shortcoming of teacher training programs, according to the author, is the predominant presence of representatives of the white race in them, that is, ignoring the cultural experience of students of color. 
In general, the authors of the works we have reviewed note a rich theoretical basis on the problem of multicultural teacher training, but the effectiveness of most theoretical foundations is not empirically confirmed, therefore, the question of fundamental changes in teacher training programs is still open. The usefulness of these analytical reviews lies in the fact that they focused on specific aspects of multicultural teacher training, which were not previously mentioned in the general goals and objectives of multicultural education.

Let us consider how this problem is studied by Ukrainian scientists. Analysis of works on reforming pedagogical education in Ukraine, taking into account the goals and objectives of multicultural education, confirmed that scientists are conducting active research in this area due to the contradiction between the real need of society for teachers of a new type and lack of attention of higher and secondary vocational education to preparing teachers for work at a multicultural educational institution [2; 15; 16; 24].

Researchers emphasize that, in the process of organization of teaching and educational work with students, their preparation for work in a multicultural educational environment is not singled out as a special purpose. The results of experiments show that students' desires to show their positive attitudes toward representatives of other cultures often do not find any adequate expression due to stereotypes formed, inability to construct dialogical forms of communication, to analyze a situation, to identify a problem, and to propose solutions to it.

The effectiveness of multicultural training students depends on the coherence of the goals and objectives of vocational training and multicultural education, the clarity and consistency of the requirements facing a future teacher. Ukrainian scientists consider the following components of pedagogical education to be important in the context of a multicultural society:

- knowledge by a teacher of the objectives, main ideas, and concepts of multicultural education; cultural, ethnohistorical, and ethno-psychological knowledge allowing to realize the diversity of the modern world and the specifics of cultural manifestations at the level of personality, group, society, to ensure understanding the importance of cultural pluralism for an individual and society; - the ability to single out or to incorporate into the content of general education ideas reflecting the cultural diversity of the world, of a country, of an ethnic group; - the ability to organize the pedagogical process as a dialogue of bearers of different cultures in time and space.

Let us note the general points that are clearly traceable in the requirements for the professionalism of Ukrainian, American and Canadian teachers necessary for work at a multicultural educational institution. Scientists in the United States and Canada unanimously emphasize that the multicultural literacy of a teacher starts, first of all, with his/her knowledge of the culture of his/her people (ethnic group) and with clear understanding his/her cultural identity; otherwise, the teacher will not be able to act as a mediator in culture and to teach students to comprehend the values that a culture holds. The authors of the concepts of multicultural education are also convinced that a teacher must be able to help his/her students in identifying their cultural identities, but at the same time remember that each student may be an intersection of several cultures, hence being a bearer of several identities.

Researchers from both countries give importance to a teacher's knowledge of the specifics of the culture of the behavior of their students or of the ethno-psychological characteristics of the students, since they affect the educational style of a child and, therefore, require the teacher to choose appropriate methods and techniques of teaching. In other words, a future teacher must learn one of the main pedagogical principles of work in a multicultural classroom, formulated in the American pedagogy by S. Nieto as follows: "equal is not the same" (i.e., equal approach does not mean the same approach) [20], which means:

- taking into account (rather than ignoring) differences between students (ethnic, language, gender, social, religious, cultural) in terms of comparison rather than superiority of some over others;

- awareness of the fact that these differences affect methods of acquisition of knowledge by students requires from a teacher the ability to adapt his/her strategy of the educational process to individual cultural styles of students;

- the ability to use cultural characteristics of students as their advantages, not disadvantages.

Researchers of both countries also include in the necessary skills of a teacher his/her ability to critically evaluate any information, to analyze his/her own cultural stereotypes, to timely rid them of them, preventing formation of biases; to remember that incorrect stereotypes affect his/her learning expectations of students.

According to scientists, an important condition for the success of a teacher's work is his/her ability to properly involve parents of their students in the educational process, to use such forms and techniques, which will intensify the educational activities of parents and raise their sense of responsibility for the education of their children.

Scientists also unanimously emphasize that the ability to create and maintain a tolerant atmosphere in the classroom is an integral part of a teacher's professionalism.

In the approaches of American and Canadian scholars to this issue, the professional pedagogical orientation of students' training recedes into the background, putting forward as a primary task formation in students of active civic positions, of the need for participation in managerial, political, and social processes at different levels (of the educational institution, the city, the district, the state) and becoming an agent of social and political transformations in society. We believe that this desire to educate the younger generation as ac- 
tive members of their lives and society with a sense of responsibility for the fate of the country, for its socioeconomic prosperity, able to, rather than being passive recipients of the current situation, influence, if necessary, the circumstances for themselves, independently making decisions in case of choice, originates from such historical preconditions of multicultural education in the United States as socio-political movements for human rights and freedoms, the feminist movement, and the fight of ethnic minorities for the preservation of their own cultural traditions.

If we compare the stages of the formation and development of multicultural education in the United States and Canada, then we will notice that active filling of the content of education with material of ethnic and cultural nature dates from the 1960s-1970s. As a result, American and Canadian educations were of interethnic and intercultural nature, considering problems of teaching and education in a narrow context, that is, in conjunction with only ethnic and cultural issues. But, as the practice of North American schools has shown, the study of these peculiarities of peoples is a necessary, but insufficient step in changing the work of the school so that it meets the needs of all students, as the causes of conflicts lie not only in ethnic and cultural differences. Education becomes multicultural if it considers learning problems in a wider context, moving beyond solving purely pedagogical tasks, namely, in conjunction with social, economic, political, religious, language, and gender differences of members of society.

Methods of the work of the Ukrainian school on the incorporation of the ethnic and cultural components into the educational process correspond to the contributory and additive approaches developed by J. Banks [3]. It is to be recalled that these approaches do not involve radical changes in the structure and goals of the main program; ethnic material serves as an addition to the existing content. However, as the author of the concept emphasizes, these approaches are necessary successive stages of transformation of educational programs, considering the goals and objectives of multicultural education.

Conclusions. Analyzing the main factors that slow down the spread of multiculturalism in the US education system, scientists point out that institutional racism remains a serious obstacle. It is to be recalled that, in contrast to individual racism, which involves only personal prejudice against representatives of other cultures, institutional racism has the power to provide with or deprive a person of certain rights and opportunities in various fields through the activities of social institutions. According to researchers, resistance to institutional racism is impossible without appropriate legislative changes. In further work on the content of curricula, Ukrainian experts can derive benefit from becoming familiar with the transformational approach and the approach of "social action" proposed by J. Banks, since they will help to carry out further transition from simple filling the content of programs with ethnic material to more complex transformations from the perspective of multicultural education.

\section{תimepamypa}

1. Avery, P., \& Walker, C. (1993). Prospective teachers' perceptions of ethnic and gender differences in academic achievement. Journal of Teacher Education. 44 (I). P. 27-37. [in English]

2. Bakhov, I. S. (2013). Multicultural education of the U.S. in fundamental legislative acts. World Applied Sciences Journal 27 (Education, Law, Economics, Language and Communication). 28-31. [in English]

3. Banks, J.A. \& C.A.M. Banks. (2000). Approaches to multicultural curriculum reform. Multicultural education: Issues and perspectives. Needham Heights, MA: Allyn \& Bacon. P. 195-214. [in English]

4. Baptiste, H., \& Baptiste, M. (1980). Competencies toward multiculturalism. Multicultural teacher education: Preparing teacher educators to provide educational equity. Washington, DC: American Association of College for Teacher Education. 405 p. [in English]

5. Bennet, C.L, Cole, D., \& Thomson, J.N. (1999). Teacher education in a collaborative multicultural classroom: Implications for critical-mass-minority and all-minority classes at a predominantly White university. C. L Bennet (Chair), Project TEAM. Symposium conducted at the meeting of the American Educational Research Association, Montreal, Canada. 506 p. [in English]

6. Casrto, A. J. (2014). The role of teacher education in preparing teachers for critical multicultural citizenship. Journal of Social Stidies Research 38(4):189-203.

7. Cochran-Smith, M. \& Fries, K (2001). Sticks, stones, and ideology: The discourse of teacher education. Educational Researcher. 30 (8). 3-15. [in English]

8. Cochran-Smith, M. (1995). Color blindness and basket making are not the answers: Confronting the dilemmas of race, culture, and language diversity in teacher education. American Educational Research Journal. 32 (3). 493-522. [in English]

9. Darling-Hammond, L., \& Sclan, E.M. (1996). Who teaches and why. Handbook of research on teacher education. New York: Simon \& Schuster. 67-101.

10. Gay, G. (2008). The importance of Multicultural Education. In David J. Flinders \& Stephen J. Thompson (eds). The Curriculum Studies Reader. Routledge. [in English]

11. Gollnick, D. M., \& Chinn, P.C. (2006). Multicultural education in a pluralistic society. New Jersey: Merrill Prentice Hall. 404 p. [in English]

12. Gordon, B. (2006). Knowledge construction, competing critical theories, and education. In J. Banks, \& C.A.M. Banks. Handbook of research on multicultural education. San Francisco: Jossey-Bass. P. 184-202. [in English]

13. Grant, C \& Secada, W. (1990). Preparing teachers for diversity. Handbook of research on multicultural education. Old Tappan, NJ: Macmillan. P. 403-422. [in English]

14. Graue, E., \& Grant, C. (2002). Questions, calls, and conversations for researchers in teacher education. Journal of Teacher Education. 52 (2). [in English] 
15. Holovatyi, M. (2014). Multiculturalism as a means of nations and countries interethnic unity achieving. Economic Annals-XXI, 11-12, 15-18. [in English]

16. Kotenko, O. V. (2008). Multicultural education of teachers. Bulletin of postgraduate education: a collection of scientific works. Issue 7.66 - 73. [in Ukrainian]

17. Ladson-Billings, G. \& Tate, W.F. (1995). Toward a critical race theory of education. Teachers College Record. (97). P. 47-68. [in English]

18. Levinson, M. (2009). Mapping multicultural education. In Harvey Siegel (ed.), The Oxford Handbook of philosophy of education. Oxford University Press. [in English]

19. National Commission on Teaching and America's Future. Doing what matters most: Investing in quality teaching. New York, 1997. 367 p. [in English]

20. Nieto, S. (2002). We speak in many tongues: Linguistic diversity and multicultural education. Multicultural education for the twenty-first century. Washington, DC: National Education Association, 389 p. [in English]

21. Sleeter, C. (2001). Culture, difference and power. New York: Teachers College Press. 325 p. [in English]

22. Toppo, G. (2001). Bush to sign education bill, but the debate over required testing goes on. Washington Post. Jan. 7. [in English]

23. Villegas, A., \& Lucas, T. (2002). Educating culturally responsive teachers: A coherent approach. Albany, NY: SUNY Press. 222p. [in English]

24. Якса, Н. В. (2015). Поликультурное образование: Европейское измерение. Проблемы современного педагогического образования. Серия Педагогика и психология. Т.46 (2). С. 354-361. [in Russian]

\section{References}

1. Avery, P., \& Walker, C. (1993). Prospective teachers' perceptions of ethnic and gender differences in academic achievement. Journal of Teacher Education. 44 (I). 27-37. [in English]

2. Bakhov, I. S. (2013). Multicultural education of the U.S. in fundamental legislative acts. World Applied Sciences Journal 27. Special issue (Education, Law, Economics, Language and Communication). 28-31. [in English]

3. Banks, J.A. \& C.A.M. Banks. (2000). Approaches to multicultural curriculum reform. Multicultural education: Issues and perspectives. Needham Heights, MA: Allyn \& Bacon. 195-214. [in English]

4. Baptiste, H., \& Baptiste, M. (1980). Competencies toward multiculturalism. Multicultural teacher education: Preparing teacher educators to provide educational equity. Washington, DC: American Association of College for Teacher Education. 405 p. [in English]

5. Bennet, C.L, Cole, D., \& Thomson, J.N. (1999). Teacher education in a collaborative multicultural classroom: Implications for critical-mass-minority and all-minority classes at a predominantly White university. C. L Bennet (Chair), Project TEAM. Symposium conducted at the meeting of the American Educational Research Association, Montreal, Canada. 506 p. [in English]

6. Casrto, A. J. (2014). The role of teacher education in preparing teachers for critical multicultural citizenship. Journal of Social Studies Research 38(4):189-203. [in English]

7. Cochran-Smith, M. \& Fries, K (2001). Sticks, stones, and ideology: The discourse of teacher education. Educational Researcher. 30 (8). 3-15. [in English]

8. Cochran-Smith, M. (1995). Color blindness and basket making are not the answers: Confronting the dilemmas of race, culture, and language diversity in teacher education. American Educational Research Journal. 32 (3). 493-522. [in English]

9. Darling-Hammond, L., \& Sclan, E.M. (1996). Who teaches and why. Handbook of research on teacher education. New York: Simon \& Schuster. 67-101. [in English]

10. Gay, G. (2008). The importance of Multicultural Education. In David J. Flinders \& Stephen J. Thompson (eds). The Curriculum Studies Reader. Routledge. [in English]

11. Gollnick, D. M., \& Chinn, P.C. (2006). Multicultural education in a pluralistic society. New Jersey: Merrill Prentice Hall. 404 p. [in English]

12. Gordon, B. (2006). Knowledge construction, competing critical theories, and education. In J. Banks, \& C.A.M. Banks. Handbook of research on multicultural education. San Francisco: Jossey-Bass. 184-202. [in English]

13. Grant, C \& Secada, W. (1990). Preparing teachers for diversity. Handbook of research on multicultural education. Old Tappan, NJ: Macmillan. 403-422. [in English]

14. Graue, E., \& Grant, C. (2002). Questions, calls, and conversations for researchers in teacher education. Journal of Teacher Education. 52 (2). [in English]

15. Holovatyi, M. (2014). Multiculturalism as a means of nations and countries interethnic unity achieving. Economic Annals-XXI, 11-12, 15-18. [in English]

16. Kotenko O. V. (2008). Polikulturna osvita vchyteliv. Visnyk pisliadyplomnoi osvity : zb. nauk. pr. - 2008. Vyp. 7. - S. 66 - 73. [in Ukrainian]

17. Ladson-Billings, G. \& Tate, W.F. (1995). Toward a critical race theory of education. Teachers College Record. (97). P. 47-68. [in English]

18. Levinson, M. (2009). Mapping multicultural education. In Harvey Siegel (ed.), The Oxford Handbook of philosophy of education. Oxford University Press. [in English]

19. National Commission on Teaching and America's Future. Doing what matters most: Investing in quality teaching. New York, 1997. 367 p. [in English]

20. Nieto, S. (2002). We speak in many tongues: Linguistic diversity and multicultural education. Multicultural education for the twenty-first century. Washington, DC: National Education Association, 389 p. [in English]

21. Sleeter, C. (2001). Culture, difference and power. New York: Teachers College Press. 325 p. [in English]

22. Toppo, G. (2001). Bush to sign education bill, but the debate over required testing goes on. Washington Post. Jan. 7. [in English]

23. Villegas, A., \& Lucas, T. (2002). Educating culturally responsive teachers: A coherent approach. Albany, NY: SUNY Press. 222p. [in English] 
24. Yaksa, N.V. (2015). Multicultural education: The European dimension. Problems of modern teacher education. Ser. Pedagogy and Psychology. Vol. 46 (2). 354-361 [in Russian].

Стаття надійшла до редакції 15.09.2018 p.

УДК 008.001.2

\author{
Яковлев Олександр Вікторович \\ доктор культурології, доцент, \\ професор кафедри мистецтвознавчої експертизи \\ Національної академії керівних кадрів \\ культури і мистецтв \\ ORCID 0000-0002-5881-0861 \\ yalikdeveloper@gmail.com
}

\title{
ФЕСТИВАЛЬНИЙ РУХ ЯК ЧИННИК ІНТЕГРАЦІЇ ТА ЗБЕРЕЖЕННЯ НАЦІОНАЛЬНОГО КУЛЬТУРНОГО ЛАНДШАФТУ
}

\begin{abstract}
Метою дослідження $є$ розкрити значення та особливості фольклорно-фестивального руху в процесі фрормування сучасного культурного простору України. Методологія дослідження побудована з урахуванням необхідності використання міждисциплінарного підходу, що поєднує можливості мистецтвознавства, культурології та інших гуманітарних наук. Науковою новизною статті бачиться обґрунтування нерозривного взаємозв'язку фестивального руху в Україні із загальносвітовими культуротворчими процесами та визначення фестивалю фрольклору, суттєвим чинником регіональної самоідентифікації і, одночасно, найважливішим засобом міжкультурної інтеграції національного культурного ландшафту. Висновки. Розвиток фестивального руху в Україні нерозривно пов'язаний із загальносвітовими культуротворчими процесами, в контексті яких фестивалі як соціокультурний феномен із кожним роком набувають поширення. Серед заходів, покликаних позитивно вплинути на процес захисту, збереження і поширення об'єктів нематеріальної культурної спадщини, зокрема, фольклору особливе значення надається фестивалям фольклору. Важлива функція фестивалю фрольклору, що походить 3 його природи, це здійснення певної соціокультурної роботи як чинника самоідентифікації і регіональної самобутності етносу, як найактивнішого засобу міжкультурної інтеграції та синергії національного культурного простору.

Ключові слова: фестивальний рух; фестиваль фольклору; культурний простір; культурний ландшафт; фольклор.

Яковлев Александр Викторович, доктор культурологии, доцент, профресор кафедры искусствоведческой экспертизы Национальной академии руководящих кадров культуры и искусств шафта

Фестивальное движение как фактор интеграции и сохранения национального культурного ланд-

Целью исследования является раскрыть значение и особенности фольклорно-фрестивального движения в процессе формирования современного культурного пространства Украины. Методология исследования построена с учетом необходимости использования междисциплинарного подхода, сочетающего возможности искусствоведения, культурологии и других гуманитарных наук. Научной новизной статьи видится обоснование неразрывной взаимосвязи фестивального движения в Украине с общемировыми культуротворческие процессами и определения фестиваля фольклора, существенным фактором региональной самоидентификации и, одновременно, важнейшим средством межкультурной интеграции национального культурного ландшафта. Выводы. Развитие фрестивального движения в Украине неразрывно связан с общемировыми культуротворческие процессами, в контексте которых фестивали как социокультурный феномен с каждым годом приобретают все большее распространение. Среди мер, призванных оказать положительное влияние на процесс защиты, сохранения и распространения объектов нематериального культурного наследия, в частности, фольклора особое значение придается фрестивалям фольклора. Важная функция фестиваля фольклора, происходит от его природы, это осуществление социокультурной работы как фактора самоидентификации и сохранения региональной самобытности етноса и активного средства межкультурной интеграции и синергии национального культурного пространства.
\end{abstract}

Ключевые слова: фестивальное движение; фрестиваль фольклора; культурное пространство; культурный ландшафт; фоольклор.

Yakovlev Oleksandr, doctor of Cultural Studies, associate professor, professor of National Academy of Managarial Staff of Culture and Arts

Festival movement as an integration factor and preserve the national cultural landscape

The purpose of the article is to reveal the meaning and characteristics of the folk-festival movement in the process of forming the modern cultural space of Ukraine. The methodology is based on an interdisciplinary approach, combining the possibilities of art history, cultural studies and other humanities. The scientific novelty of the article seems to be the rationale for the inextricable relationship of the festival movement in Ukraine with global cultural processes and the definition of the festival of folklore, a significant factor in regional identity and, at the same time, the most important means of intercultural integration of the national cultural landscape. Conclusions. The development of the festival movement in Ukraine is inextricably linked with the global cultural-creating processes, in the context of which

() Яковлев О. В., 2018 